Globalization has made people in one country utterly dependent on markets in others, and automation might unravel large parts of this global trade network with disastrous consequences for the weakest links. AI might generate immense wealth in hi-tech hubs such as Silicon Valley and Bangalore, while devastating the econo-

mies of underdeveloped countries that rely on cheap labour, such as Honduras and Bangladesh.

US voters might conceivably agree that taxes paid by tech giants Amazon and Google for their US business should be used to give stipends to unemployed coalminers in Pennsylvania or jobless taxidrivers in New York. But they are unlikely to send their taxes to Honduras. We are still far from having any feasible models for a post-work economy, society or political system, and we don't have much time to formulate them.

In the nineteenth century, the Industrial Revolution created new conditions and problems that none of the existing social, economic and political models could cope with. Consequently, humankind had to develop completely new models - liberal democracies, communist dictatorships and fascist regimes. It took more than a century of terrible wars and revolutions to experiment with these, separate the wheat from the chaff and implement the best solutions.

The challenges posed in the twentyfirst century by the merger of infotech and biotech are arguably bigger than those thrown up by steam engines, railways, electricity and fossil fuels. Given the immense destructive power of our modern civilization, we cannot afford more failed models, world wars and bloody revolutions. We have to do better this time.

Yuval Noah Harari is in the Department of History, Hebrew University of Jerusalem. e-mail:ynharari@mail.huji.ac.il

1. Chui, M., Manyika, J. \& Miremadi, M. McKinsey Quarterly (2016); available at http://go.nature. com/2xt0iio

2. Cowen, T. Marginal Revolution (2013); available at http://go.nature.com/2kzkkgs

3. World Health Organization Global Status Report on Road Safety 2015 (WHO, 2016).

4. Fagnant, D. J. \& Kockelman, K. Transp. Res. Part A Policy Pract. 77, 167-181 (2015).

5. Azimi, S., Bhatia, G., Rajkumar, R. \& Mudalige, P. SAE Int. J. Passenger Cars - Mech. Syst. 4, 406-416 (2011).

6. Kumar, S. et al. SIGCOM Comp. Commun. Rev. 42, 259-270 (2012).

7. Gerla, M., Lee, E. K., Pau, G. \& Lee, U. 2014 IEEE World Forum on Internet of Things (WF-IOT) 241-246 (IEEE, 2014).

8. Hirschauge, O. \& Sheizaf H. Haaretz (2017); available at http://go.nature.com/2xswgrm (in Hebrew).

9. Harel, A. Haaretz (2017); available at http:// go.nature.com/2yaiavo (in Hebrew).

10. Henley, J. The Guardian (2017); available at http://go.nature.com/2kd2pld

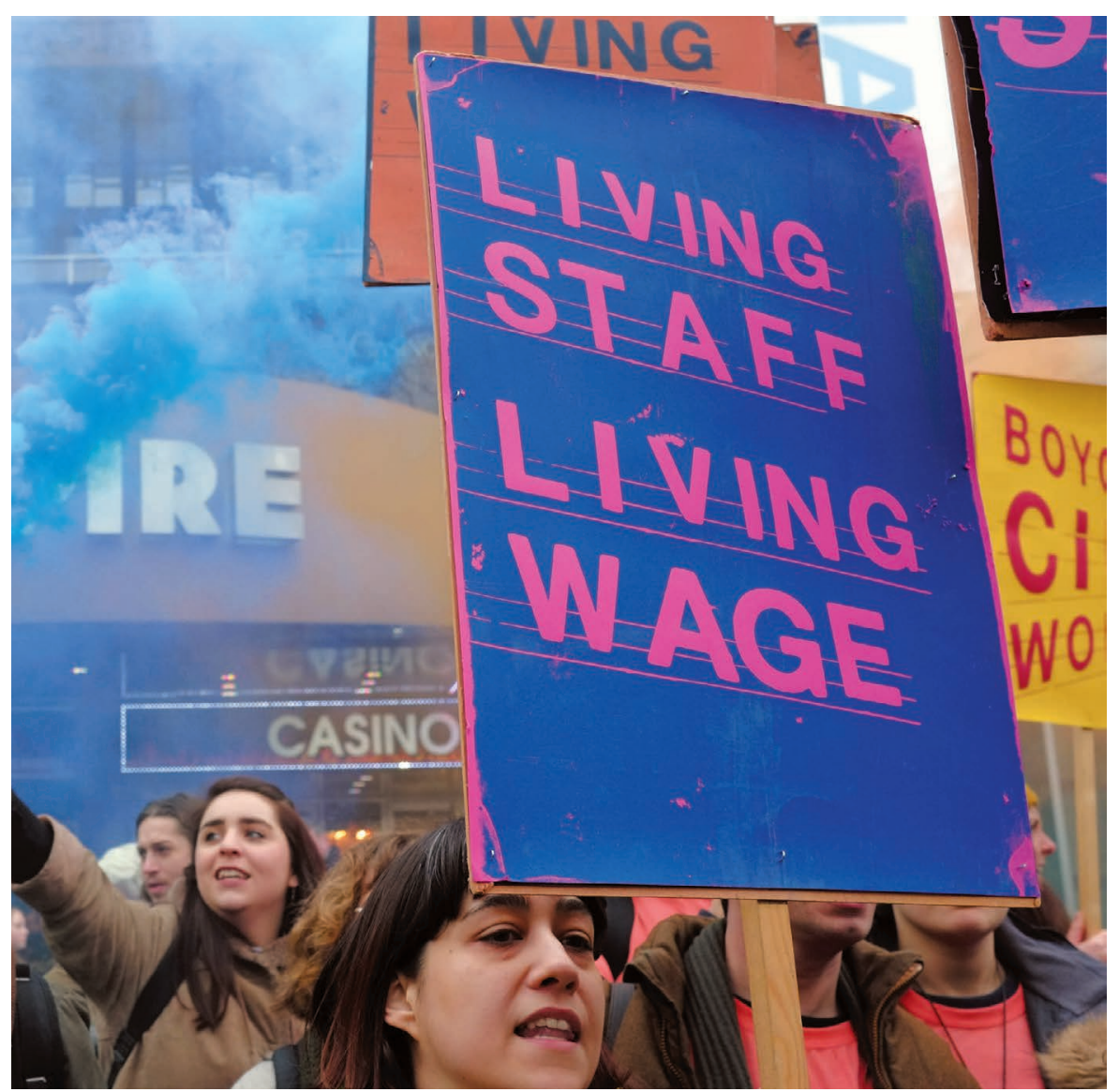

Workers protest in London in February.

\title{
The second Renaissance
}

\section{Ian Goldin calls on scientists to help society to weather the disruptive transformations afoot.}

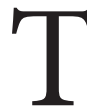

The Renaissance that began in Europe in the mid-1400s and ended in the early 1500 s brought a radical transformation of the sciences, the humanities and politics. Building on the invention of the printing press and cheap paper, information was democratized, there was a hunger for literacy and the Catholic Church's near-monopoly on knowledge was challenged. The resulting breakthroughs took Europe from being one of the more backward regions of the world to being the most advanced by far, within just 80 years.

But it ended in tears. Extremists, pointing

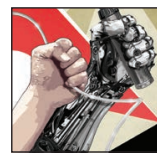

THE FUTURE OF WORK

A Nature special issue to growing inequalities and the corruption of the elite, called for a return to spiritual values. In Italy, thousands of artworks and books were burned, branded as irreverent. Across Europe, rising intolerance of scientists, intellectuals, foreigners and ethnic minorities became the norm, with religious wars and inquisitions playing out over the following centuries.

In my view, many parts of the world are now in the middle of a second Renaissance. This one is seeing even faster change than the last, and across the entire globe. History tells us that it will be disruptive. It will bring immense benefits and it will be highly destabilizing. We should expect more extremism and the rise of potentially catastrophic risks.

Innovation today is happening faster than ever, driven by the unlocking of individual $>$ 


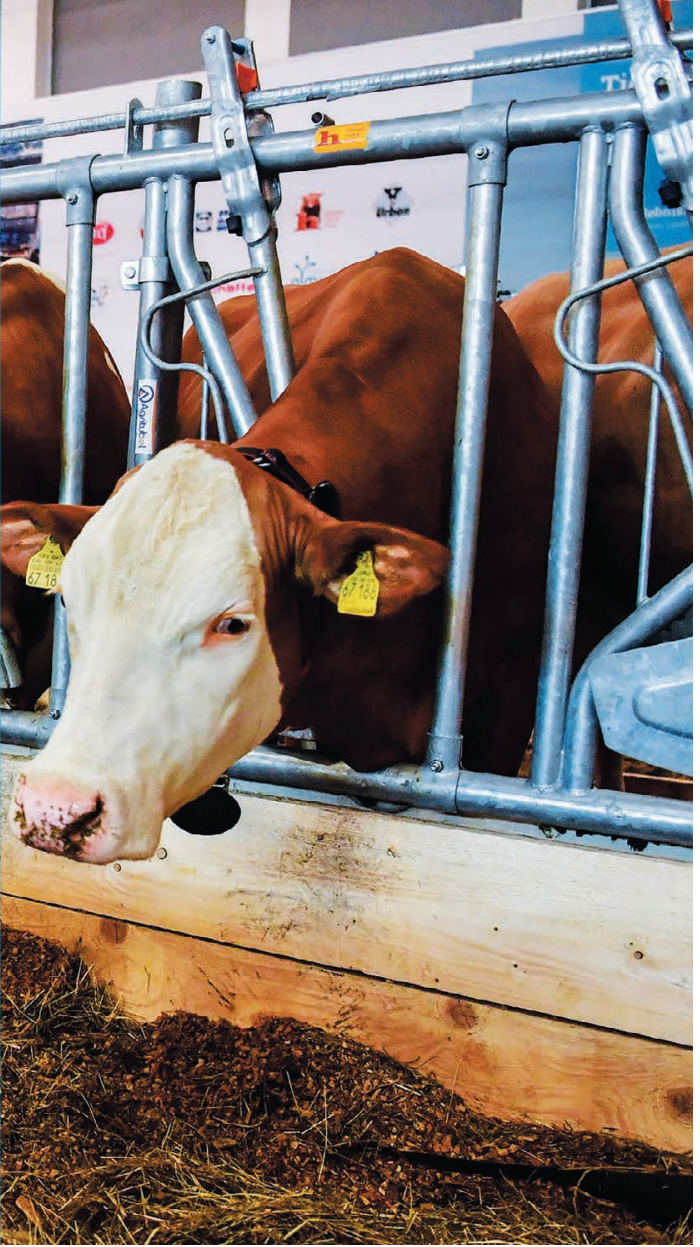

machines take over their jobs ${ }^{9}$.

Alongside their anxieties about being left behind by globalization comes a deep mistrust of the 'experts' in charge of the global systems, and a rejection of evidence. Paradoxically, although we know more than ever, rising complexity and speed of change mean that experts are likely to be wrong more often. The financial system, for example, is home to numerous highly qualified experts, housed in a formidable array of powerful institutions, who are handsomely paid to secure economic stability. Yet, as the 2008 financial crisis demonstrated, they have proved dismally unequal to the task. Similarly, experts in the European Commission seem to have failed to control reporting of emissions from leading car manufacturers. Little wonder that trust in authority has been severely eroded. When the evidence threatens entrenched elites, scepticism regarding expertise becomes particularly poisonous. Trump's dismissal of the science of climate change is an egregious example of this trend.

The flourishing of science was contested in the original Renaissance, too. Printing presses provided the means for experts and intellects to share knowledge, but also allowed fake news to flourish. In Medici Florence, fundamentalist Italian preacher Girolamo Savonarola circumvented the authority of popes and princes with the mass production of one-page pamphlets - the equivalent of today's tweets. Both Savonarola and the clergy denied that Earth went around the Sun, and that the heart was a pump.

Although history does not repeat itself, it does rhyme. In the United Kingdom, campaigners successfully used social media to convince people to support Brexit even when it was against their interests, as in the case of farmers who receive subsidies from the European Union. In the United States, social media that propagated fears rather than facts played a key part in shaping the outcome of the 2016 presidential election ${ }^{10}$.

\section{RAPID RESPONSE}

As societies change more rapidly, flexibility becomes more important. For individuals, it becomes more necessary to move to where the jobs are and to reskill. For governments, it is crucial to renew infrastructure and social safety nets. Regulatory frameworks also need to evolve rapidly, to address a widening range of risks - from the genetic enhancement of humans to geoengineering.

Unfortunately, at a time when the need to renew and invest in the future is rising, the ability of governments to keep pace with change is being undermined. The use of off-shore tax havens - notably by companies at the frontier of technological change - as well as competition by governments to attract increasingly mobile individuals and companies by reducing taxes, together with austerity policies, have reduced the capacity of governments to invest in health, education, infrastructure, social security, research and other expenditures ${ }^{11}$. Lower investment leads to lower growth and political gridlock, as politicians fight over the allocation of fixed or diminishing resources.

Stronger safety nets are necessary to prevent poor and vulnerable individuals and families from being undermined by technological and other changes. If not, social cohesion will be eroded, fanning the flames of populist push-back against change and all things foreign.

Some Silicon Valley billionaires, fearing revolt against the growing wage gap, along with some social activists, have called for the introduction of a Universal Basic Income (UBI) for people working and not. But a UBI is not a panacea. The Organisation for Economic Co-operation and Development has shown that the policy could, perversely, increase inequality and poverty. And, because jobs are so important to our status and self-worth, having money alone does not protect against the increases in morbidity, criminal activity, opioid and alcohol abuse that have been associated with unemployment ${ }^{12}$.

Instead, we need a broader change in attitudes towards work. We need to remove the stigmas associated with part-time employment, retirement and volunteer work. We should nurture a greater respect and pay for creative, caring and home-based activities.
There are reasons for optimism. There are more scientists alive today than all those who previously lived; citizen science adds millions more. As well as more minds at work, there are more-diverse collaborations, thanks to greater gender equality and the participation of more nations and peoples. The probability of unlocking mysteries and finding solutions to great challenges is rising, as is the global dissemination of the benefits. Cross-border collaborative projects, from the CERN particle-physics laboratory near Geneva, Switzerland, to the Human Genome Project, highlight the benefits of cooperative activity, in stark contrast to isolationist politics.

Now, more than ever, scientists must engage and communicate, to ensure that science is not overrun by politics. Renaissance moments are associated with an intensifying battle of ideas. Scientists need to engage in this struggle over the development and application of their expertise and inventions.

In the first Renaissance, extremists won; reason and evidence did not prevail. In our second Renaissance, knowledge and enquiry must find a way to conquer prejudice and ignorance. Scientists know that they can never progress through isolationism or ignorance. Nor can our societies.

Ian Goldin is professor of globalization and development at the University of Oxford, UK. His website is at iangoldin.org, and he tweets@ian_goldin

1. Goldin, I. The Pursuit of Development: Economic Growth, Social Change and Ideas (Oxford Univ. Press, 2016).

2. Goldin, I. \& Kutarna, C. Age of Discovery: Navigating the Storms of Our Second Renaissance (Bloomsbury, 2017).

3. Goldin, I. \& Mariathasan, M. The Butterfly Defect: Why Globalization Creates Systemic Risks, and What to Do About It (Princeton Univ. Press, 2014).

4. Nolan, B. et al. Inequality and Prosperity in the Industrialized World: Addressing a Growing Challenge (Citigroup, 2017); available at http:// go.nature.com/2xm5hpy

5. Dao, M. C., Das, M., Koczan, Z. and Lian, W. In World Economic Outlook, April 2017: Gaining Momentum? Ch. 3 (IMF, 2017); available at http:// go.nature.com/2y $52 \mathrm{mxch}$

6. Frey, C. B. et al. Technology at Work v2.0: The Future Is Not What It Used to Be (Citi GPS, 2016) available at http://go.nature.com/2xvaukm

7. Wilkie, M. et al. Technology at Work v3.0: Automating e-Commerce from Click to Pick to Door (Citi GPS, 2017); available at http://go.nature. $\mathrm{com} / 2 \mathrm{y} 4 \mathrm{q} 717$

8. Goldin, I., Cameron, G. \& Balarajan, M. Exceptional People: How Migration Shaped Our World and Will Define Our Future (Princeton Univ. Press, 2011).

9. Frey, C. B., Berger, T. \& Chen, C. Political Machinery: Automation Anxiety and the 2016 U.S. Presidential Election (Oxford Martin School, 2017); available at http://go.nature.com/2hporgq

10.Allcott, H. \& Gentzkow, M. J. Econ. Perspect. 31, 211-236 (2017).

11.Crivelli, E., De Mooij, R. \& Keen, M. Base Erosion, Profit Shifting and Developing Countries IMF Working Paper WP/15/118 (IMF, 2015); available at http://go.nature.com/2kp944q

12. Case, A. \& Deaton, A. Mortality and Morbidity in the 21st Century Brookings Papers on Economic Activity (Brookings Institution, 2017); available at http://go.nature.com/2hfjx6r 